
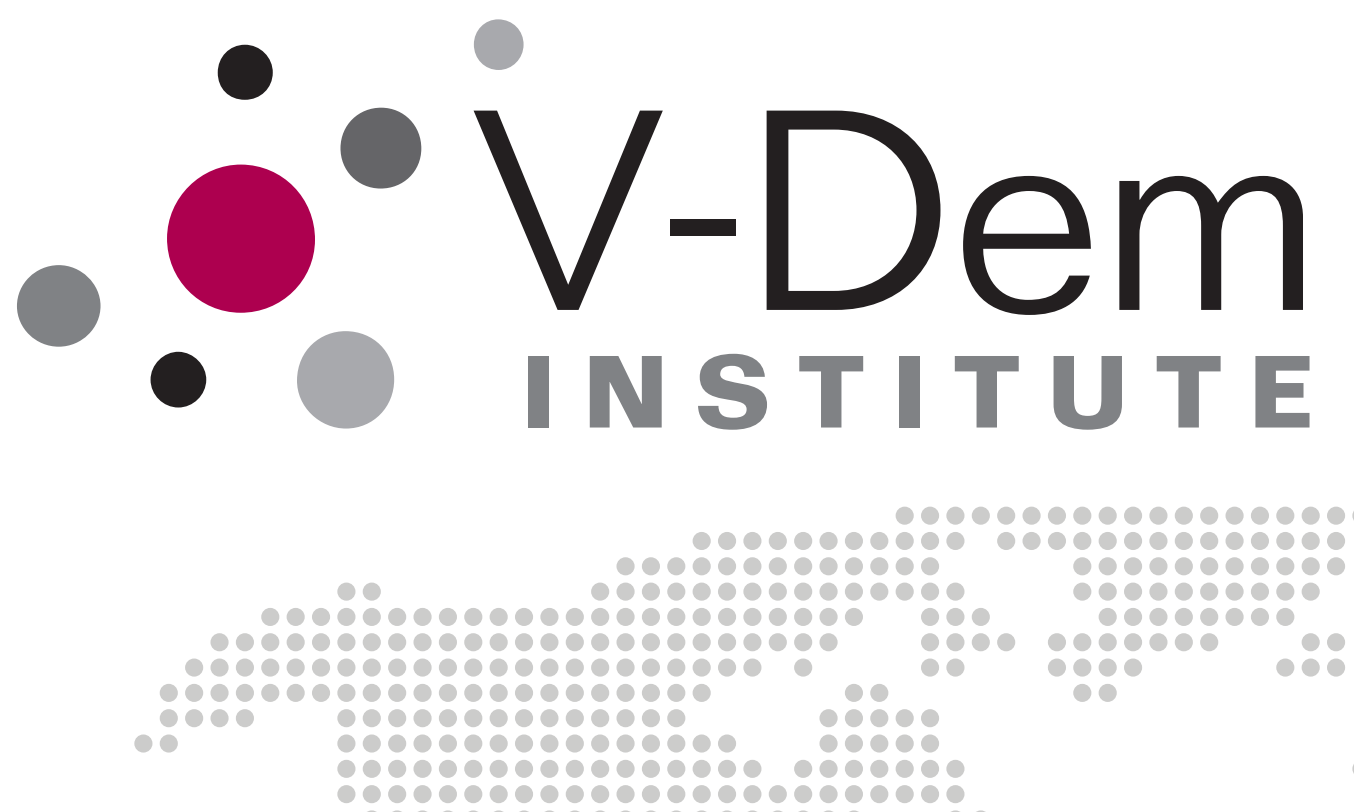

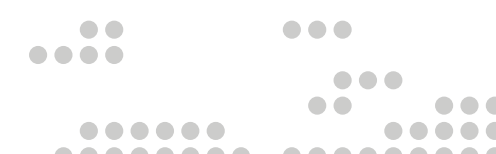
2060

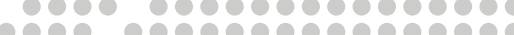

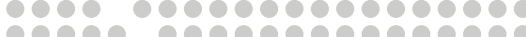

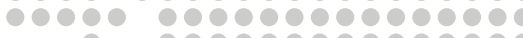

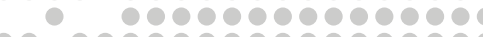

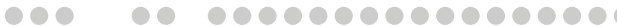

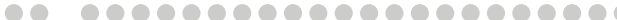

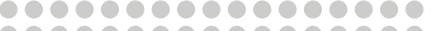
190000000000000000

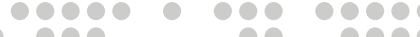
Establishing Pathways to Democracy Using Domination Analysis

0000000000000

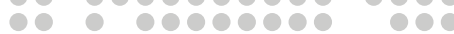

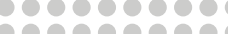

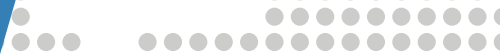

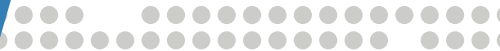

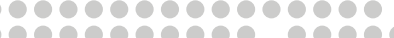

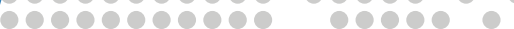

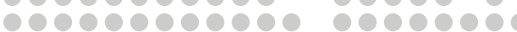

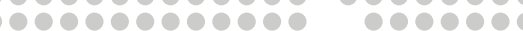

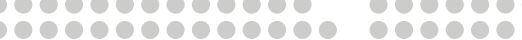
Amanda B. Edgell, Vanessa A. Boese, Seraphine F. Maerz, Patrik Lindenfors, Staffan I. Lindberg

0000
0000000
000000
000000
0000
0090
000
00
0

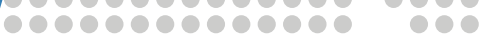
1000000000000000 p000000000000000000

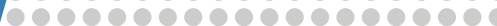

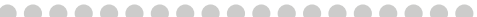

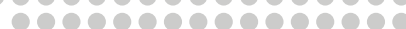
९ी000000000000 1909090909090 0000000000 0000000000 1000000000 0000000900е

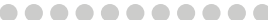
00000000000

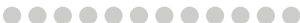
000000000

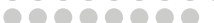
00000000 000000

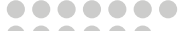
000000 1000 100

February 2020

Working Paper

SERIES 2020:95

THE VARIETIES OF DEMOCRACY INSTITUTE

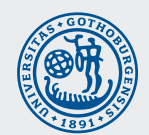

UNIVERSITY OF GOTHENBURG

DEPT OF POLITICAL SCIENCE 
Varieties of Democracy (V-Dem) is a new approach to conceptualization and measurement of democracy. The headquarters - the V-Dem Institute - is based at the University of Gothenburg with 20 staff. The project includes a worldwide team with six Principal Investigators, 14 Project Managers, 30 Regional Managers, 170 Country Coordinators, Research Assistants, and 3,000 Country Experts. The V-Dem project is one of the largest ever social science research-oriented data collection programs.

Please address comments and/or queries for information to:

V-Dem Institute

Department of Political Science

University of Gothenburg

Sprängkullsgatan 19, PO Box 711

SE 40530 Gothenburg

Sweden

E-mail: contact@v-dem.net

V-Dem Working Papers are available in electronic format at www.v-dem.net.

Copyright (C2020 by authors. All rights reserved. 


\title{
Establishing Pathways to Democracy Using Domination Analysis*
}

\author{
Amanda B. Edgell ${ }^{1}$, Vanessa A. Boese ${ }^{1}$, Seraphine F. Maerz ${ }^{1}$, \\ Patrik Lindenfors ${ }^{2}$, and Staffan I. Lindberg ${ }^{1}$ \\ ${ }^{1}$ V-Dem Institute, University of Gothenburg \\ ${ }^{2}$ Institute for Future Studies
}

\begin{abstract}
*Corresponding author: Amanda B. Edgell (amanda.edgell@v-dem.net). Author contribution statement: Amanda B. Edgell conducted most of the data analysis and made substantial contributions to the written text. Vanessa Boese and Seraphine F. Maerz took lead on drafting of the text, and assisted with the data analysis and interpretation. Patrik Lindenfors developed the domination analysis methodology and contributed substantially to the data analysis process. Staffan I. Lindberg made contributions to the conception and design of the paper, as well as engaging in revisions of the written text. This research project was supported by Knut and Alice Wallenberg Foundation to Wallenberg Academy Fellow Staffan I. Lindberg, Grant 2013.0166 and 2018.0144; by European Research Council, Grant 724191, PI: Staffan I. Lindberg, V-Dem Institute, University of Gothenburg, Sweden; Marianne and Marcus Wallenberg Foundation to Patrik Lindenfors, Grant 2017.0049; as well as by internal grants from the Vice-Chancellor's office, the Dean of the College of Social Sciences, and the Department of Political Science at University of Gothenburg. Replication files will be uploaded here: https://github.com/vdeminstitute
\end{abstract}




\section{Abstract}

How does the order in which liberalization unfolds affect the likelihood for a successful democratic transition? Dahl was among the first to argue that the sequence matters for the outcome when it comes to democratization. This paper builds upon his work and empirically analyzes pathways to democracy employing the newly developed method of domination analysis. We are the first to demonstrate three key findings: 1) There is a clear structure in terms of order of how most episodes of liberalization from authoritarian rule develop; 2) Such sequences are different in key respects for failed and successful episodes of liberalization; and 3) clean election elements - in the capacity of electoral management bodies - stand out as developing earlier in episodes that successfully lead to democracy. 


\section{Introduction}

Which factors determine whether a democratizing country evolves into a stable democracy? While much of the literature is concerned with exogenous explanations of democratization (e.g. Lipset, 1959; Przeworski et al., 2000; Boix and Stokes, 2003), we focus on endogenous dynamics, i.e. the "sequence of transformations of a regime and the way in which a new regime is inaugurated" with attention to the specific institutional guarantees necessary for electoral democracy (or "polyarchy") as outlined by Dahl (1971, p. 33). Are there identifiable patterns of institutional reform during episodes of political liberalization from authoritarian rule? Are there observable differences in these patterns between episodes that resulted in a democratic transition and those that did not? Which of these differences are critical for determining liberalization outcomes? This paper answers these questions empirically and provides descriptive evidence that will enhance our understanding of how democratization unfolds.

Previously, scholars have alluded to potential paths to democracy, most notably, the timing of political competition versus participation (e.g. Dahl, 1971; Huntington, 1968; O‘Donnell and Schmitter, 1986), but until now, we lacked sufficient data and methods to investigate the details of how democracy develops. With detailed measures from the Varieties of Democracy (V-Dem, Coppedge et al., 2019b), a large sample of liberalization episodes from 1900 to 2018 (FASDEM), and new domination analysis techniques adapted from sequencing methods in evolutionary biology (Lindenfors et al., 2018; Lindenfors, Krusell, and Lindberg, 2019), we can for the first time identify the relative order of how electoral democracy develops. Deciphering the pattern of development across the ordinal scales of 24 components of electoral democracy (Teorell et al., 2019), the domination analysis identifies which institutional reforms came earlier in the liberalization sequence. We then compare how these sequences differ for episodes ending in a democratic transition and those that faltered.

Our findings provide several novel insights for the literature on democratization. We are the first to demonstrate that: 1) There is a clear order in how most episodes of liberalization from authoritarian rule develop; 2) Such sequences are different in key respects for failed and successful episodes of liberalization; and 3) Clean election elements, particularly the capacity of electoral management bodies (EMBs), develop earlier in episodes ending with a successful 
Table 1. Elements of Polyarchy

\begin{tabular}{llll}
\hline Suffrage & Clean elections & $\begin{array}{l}\text { Freedom of expression and } \\
\text { alternative sources of information }\end{array}$ & Freedom of association \\
\hline Suffrage & EMB autonomy & Government media censorship & Party ban \\
& EMB capacity & Harassment of journalists & Barriers to parties \\
& Voter registry & Media bias & Opposition parties autonomy \\
Vote buying & Media self-censorship & Elections multiparty \\
Other voting irregularities & Media critical & CSO entry and exit \\
Election intimidation & Media perspectives & CSO repression \\
Other electoral violence & Discussion for men & \\
Election free and fair & Discussion for women & \\
& & Academic and cultural expression & \\
\hline
\end{tabular}

Note: We use re-scaled versions of media critical, media perspective, media self-censorship, and suffrage so that all variables are measured on an ordinal scale from 0-4. For more information please see Coppedge et al., 2019a.

democratic transitions, when compared to those that do not produce regime change. These results reveal unique insights on how democratic transitions unfold that have important practical implications for democracy promotion. Future work can extend this to provide clues as to how to protect democracy during the current "third wave of autocratization" (Lührmann and Lindberg, 2019).

\section{Materials and Methods}

We employ a conceptualization of democracy based on Dahl's (1971) notion of polyarchy, measured using the Electoral Democracy Index (EDI) by V-Dem (Coppedge et al., 2019b; Teorell et al., 2019). Covering 180 countries from 1900 to 2018, the EDI includes indicators for the six institutional guarantees highlighted by Dahl $(1971 ; 1989 ; 1998)$. These data are uniquely designed to allow for fine-grained analysis of disaggregated indicators of democracy. We focus on the 24 key indicators included in the component-indices for suffrage, clean elections, freedom of expression, alternative sources of information, and freedom of association (see Table 1) 1 1

To identify democratization episodes, we follow a slightly modified version of the FASDEM method described in Lindberg et al. (2018) that identifies periods of substantial liberalization in an authoritarian regime that may or may not result in a successful democratic ${ }^{1}$ Omitting the elected officials index due to limited variation. 
transition $2^{2}$ To be considered substantial, the country must experience a net change $\geq 0.10$ on the EDI during a period of time when it does not also experience any net annual declines of $\geq 0.02$ (which is considered onset of autocratization), prolonged periods of statsis (i.e. no positive change for ten years), or a slow decline of $\geq 0.10$ over ten years. Our scope is limited to liberalization periods that start in authoritarian regimes since we are interested in exploring the process of reforms leading to democratic transition, leaving aside questions of further liberalization in democracies for future research. Following the case study literature (e.g. O`Donnell and Schmitter, 1986; Linz and Stepan, 1996; Bratton and Walle, 1997), we consider successful democratization to occur when elected officials assume office through a "founding" democratic election $3^{3}$ Failed episodes do not achieve this criteria, either ending with a substantial drop in EDI scores (classified as failed liberalization), no change for ten years resulting in stabilized electoral authoritarianism, or a preempted transition having achieved electoral democracy but failing to hold elections before reverting back to authoritarianism. This method results in 146 successful episodes in 110 countries, 182 failed episodes in 91 countries, and nine ongoing (i.e. censored) episodes as of 2018 (using V-Dem v9, see Table A1 for a complete list).

To identify the order of reforms during these episodes, we rely on methods adapted from evolutionary models for exploring the temporal relationship between two ordinal variables (Lindenfors et al. 2018; Sillén-Tullberg 1993; used in Mechkova, Lührmann, and Lindberg 2019; Wang et al. 2017). Specifically, we analyze all possible combinations of values of all pairs of the 24 variables to establish which variables "dominate" other indicators (i.e. achieve higher values earlier), and thus establish the sequence by which elements of polyarchy develop. 4 Because the same sequence, or order of events, can play out quickly in one country and very slowly in another, we remove the year element and focus on state changes and their order, regardless of duration of transitions. To achieve this, we combine all yearly observations when values of all variables did not change into one observation and consider these as one observable "state". This also resolves the potential problem that stable states may overwhelm changes in terms of

\footnotetext{
${ }^{2}$ The FASDEM data, codebook, and all replication files are available here: blinded for review

${ }^{3}$ Based on holding elections for the legislature or executive while being rated at least electoral democracy on RoW.

${ }^{4}$ Using the R-package $\operatorname{seqR}$ : https://github.com/jsks/seqR
} 
numbers. To check that this compression does not bias the results, we report results for the uncompressed data in the replication materials.

We provide the results in domination tables indicating how many other variables each component dominates and is dominated by, meaning that it is larger or smaller than the other component in at least $50 \%$ of the observed states. Indicators dominating a high number of others can be said to develop comparatively early during an episode of democratization, while those frequently dominated are viewed as developing relatevely later. Taking the difference or "balance" between dominates and dominated by, allows us to order variables from early movers to latecomers and allows us to look for differences in the reform sequences observed for successful and failed episodes.

\section{Results}

Figure 1 reports results of the domination analysis using the full sample of democratization episodes, ordered based on the balance (i.e. difference between dominates and is dominated by). Five indicators stand out as developing comparatively early in the democratization sequence: suffrage and four related to political parties. These variables dominate the greatest number of other indicators and are (almost) never dominated by another indicator, thus exhibit the greatest balance. By contrast, components found in V-Dem's clean elections and freedom of expression indices develop comparatively late. Government media censorship, harassment of journalists, vote buying, voting irregularities, and election management body indicators never dominate but are frequently dominated by other components of electoral democracy. This is our first main result: evidence of a remarkable order across all episodes of democratization from 1900 to 2018.

Figure 2 compares successful and failed episodes. Our second main result is the striking similarities between successful and failed episodes. Those aspects of the EDI that develop relatively early and relatively late are nearly identical, with one notable exception: EMB capacity. During successful episodes, EMB capacity tends to develop toward the middle of the sequence, unlike in failed ones where it exhibits a very low balance (-16) driven by the indicator being dominated by 16 others without ever dominating. Figure 3 further illustrates this finding, plot- 


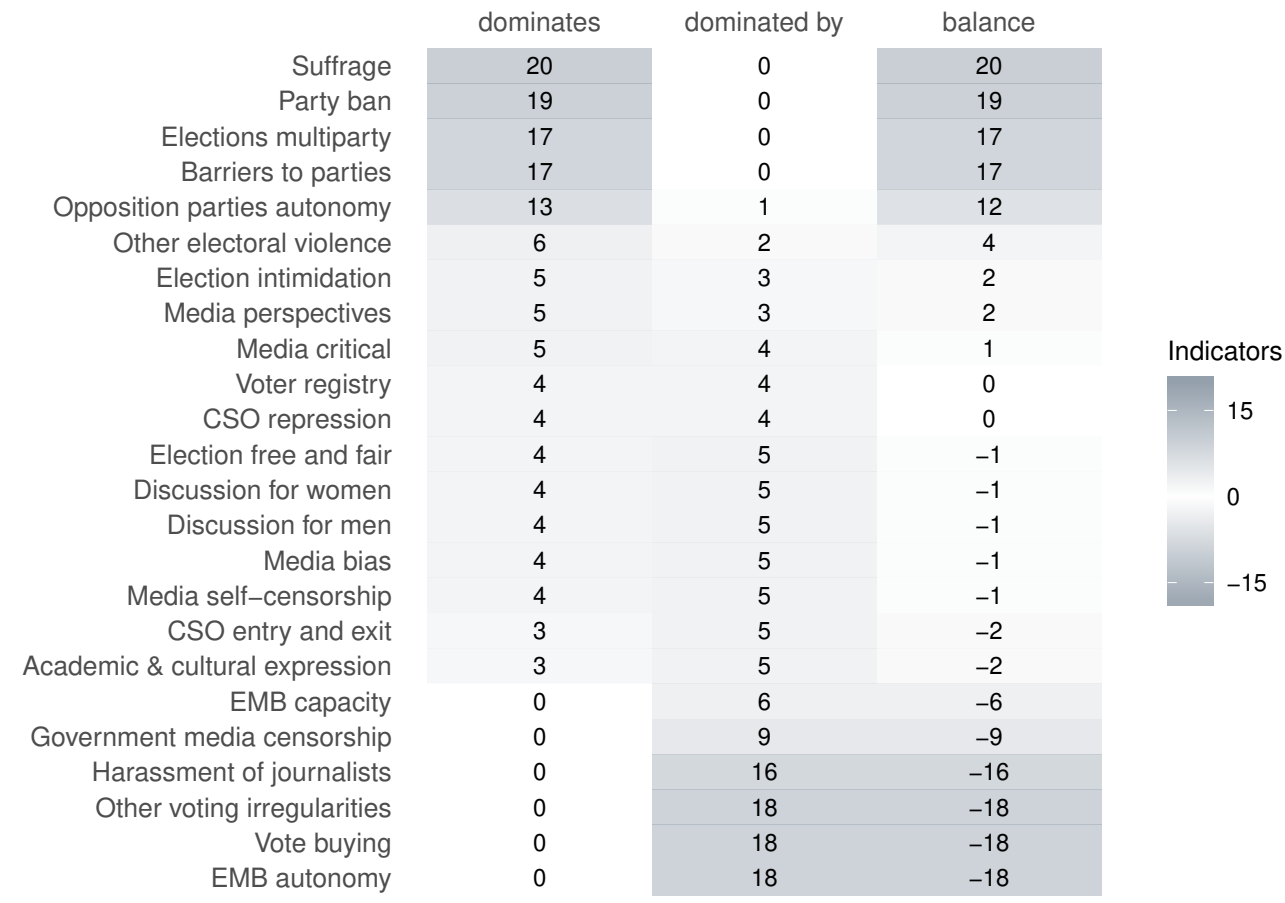

Figure 1. Domination analysis results for all observations in episodes of democratization. Reported values are the number of other components the given component is larger than (dominates) or smaller than (dominated by) in at least $50 \%$ of the observed states. Balance reflects the difference between dominates and dominated by.

ting the difference in balances for each indicator between successful and failed episodes. Higher positive values indicate that the component moves comparatively earlier in successful episodes. The sheer magnitude of the difference between failed and successful episodes for EMB capacity stands out 5 Other components from the clean election index also exhibit relatively earlier development in successful episodes, but the magnitude of the difference is not as large 6 By contrast, components of freedom of association and expression tend to move somewhat earlier in failed episodes, but again with smaller differences than EMB capacity. Thus, our third main finding is that higher levels of EMB capacity earlier on in the liberalization process distinguish those episodes that led to a successful democratization from those that failed.

We can naturally not make a causal claim at this point, but perhaps akin to switching on a genome, developing high EMB capacity earlier seems to play a critical role in the outcomes

\footnotetext{
${ }^{5}$ Figures A7, A8 and A9 of the Appendix provide network graphs as an additional visualization of these dominance relationships. The distinctness of EMB capacity is observable when comparing the graphs for failed (Figure A9p and successful episodes (Figure A8).

${ }^{6}$ Likewise, we are cautious to make any claims about these variables as their values are only measured on election years and carried forward so long as the electoral regime is uninterrupted.
} 


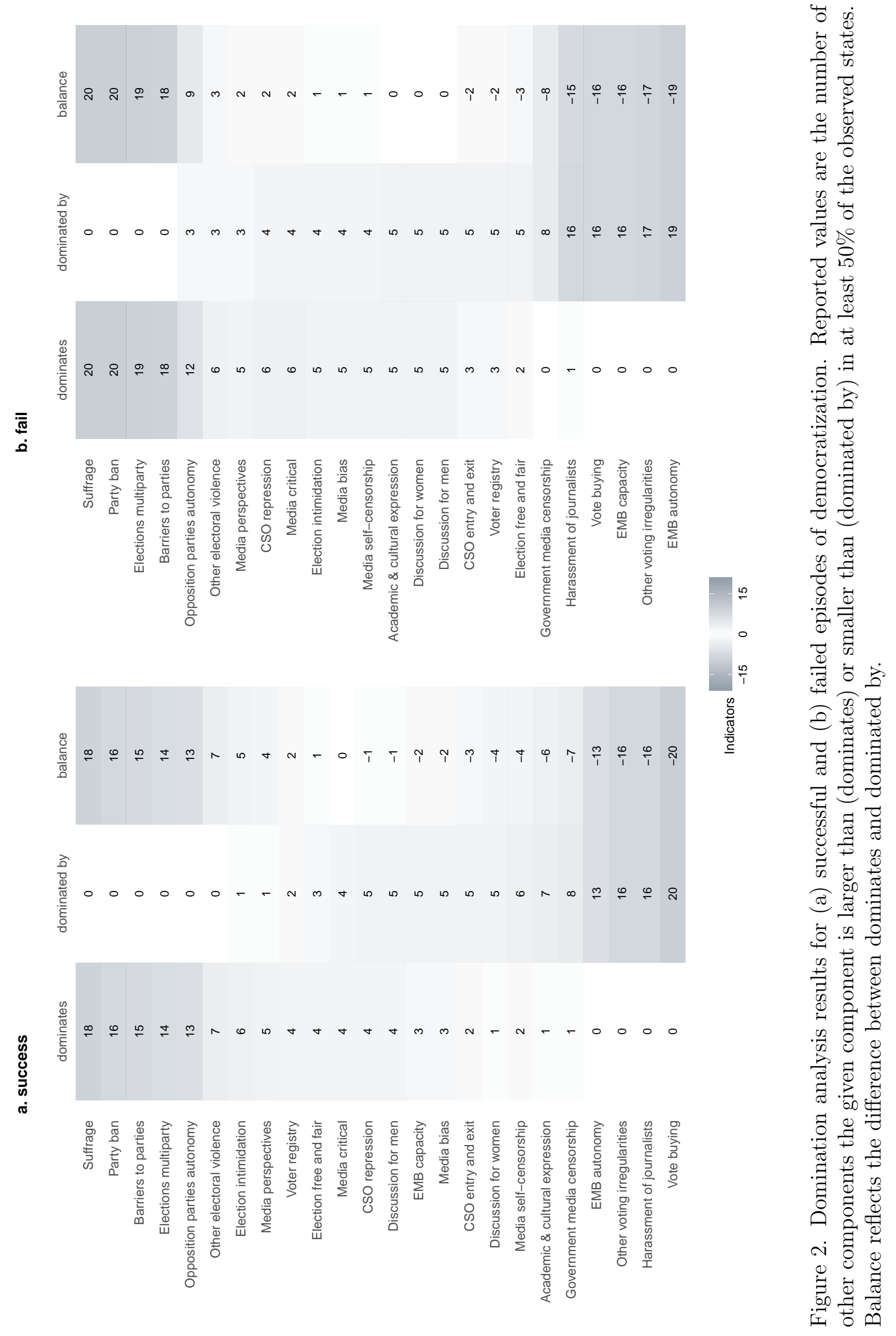




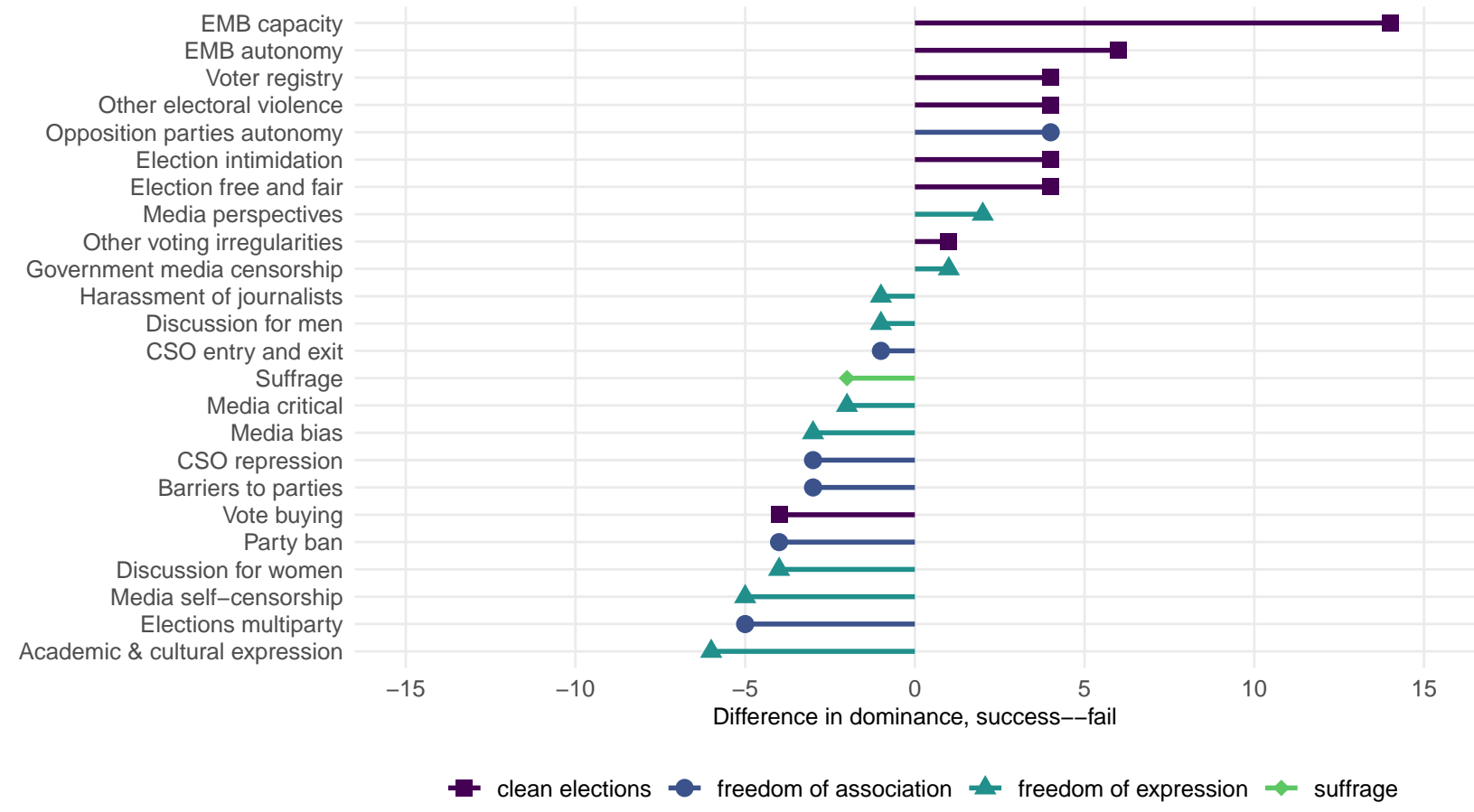

Figure 3. Difference in dominance for successful and failed episodes. Values are the difference in the balance of indicators the component dominates and is dominated by in successful versus failed episodes. Higher values suggest that the component develops earlier in successful episodes.

of liberalization processes. In particular, as shown in Figure 4, EMB capacity tends to develop later than suffrage and most of the freedom of association and expression variables and even some of the clean election indicators during failed episodes. By contrast, EMB capacity is dominated by only five indicators in successful episodes (opposition autonomy, elections multiparty, barriers to parties, party ban, and suffrage, i.e. those that also tend to come earliest in all episodes) and develops before three variables (vote buying, harassment of journalists, and other voting irregularities). It is therefore of special interest for future research to drill down deeper into which relationships to other variables are driving these observed differences and whether they are indeed causal.

In the online appendix, we also report domination analysis results for different types of failed episodes. Similar patterns emerge, especially regarding the role of EMB capacity, which continues to exhibit the greatest difference in balance between successful and all types of failed episodes. For preempted transitions, or those "near misses" for democracy, autonomy for opposition parties also comes much later than in successful episodes. Finally, in line with the 


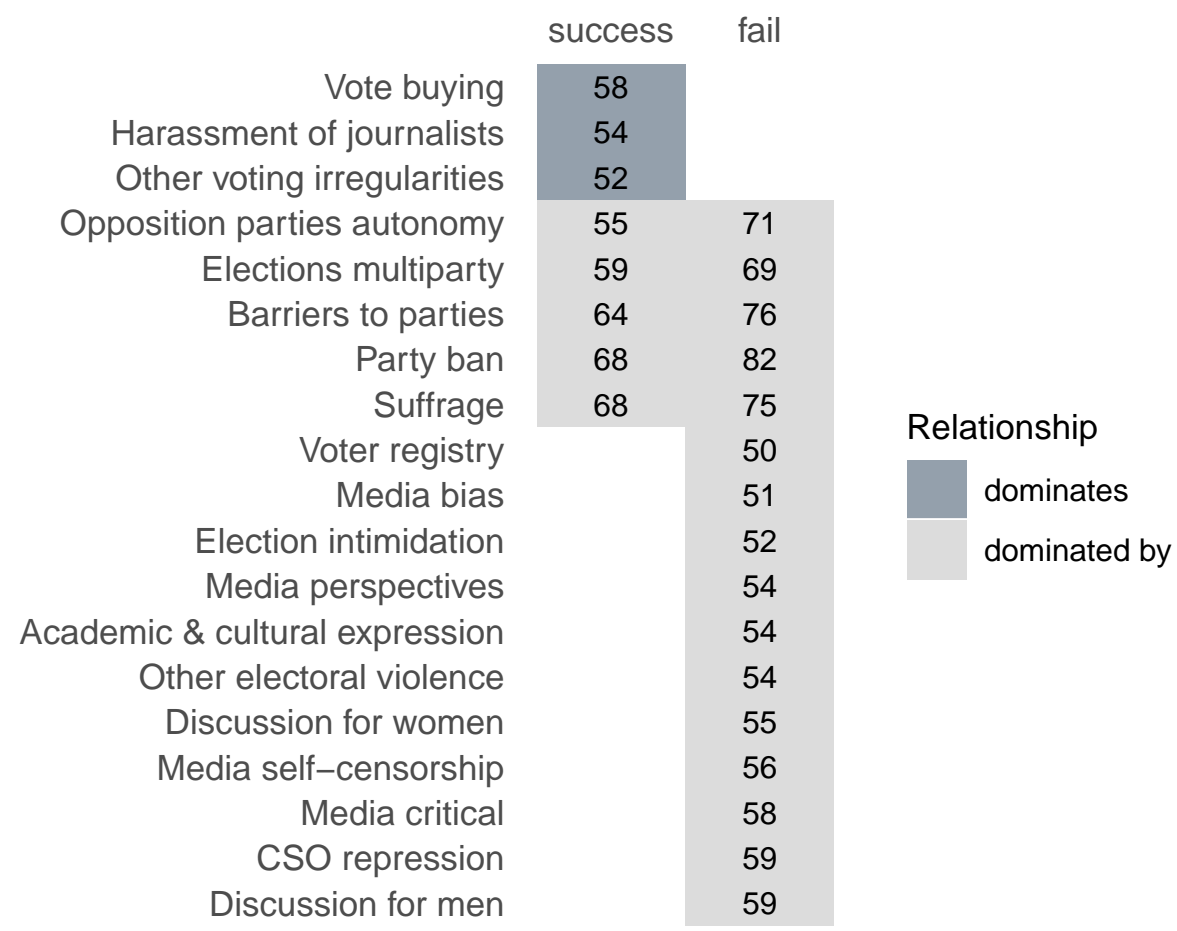

Figure 4. Dominance relationships between EMB capacity and 19 other components. Reported values are the percentage of states that EMB is greater than the other indicator if EMB dominates (darker grey) and less than the other indicator if EMB is dominated (lighter grey). Cells are white and empty if there is no clear dominance relationship between two variables (i.e. if $\mathrm{X}>\mathrm{Y}$ occurs in less than $50 \%$ of the cases)

recent literature, we see women's rights (to discussion) develop comparatively earlier for cases ending in stabilised electoral authoritarianism (Donno and Kreft, 2019; Edgell, 2019). While beyond the scope of this paper, these exploratory results provide tentative directions for future research

\section{Conclusion}

The results presented here reveal for the first time clear sequences in which the specific institutions of democracy develop during periods of liberalization. Several components of freedom of association (elections multiparty, opposition parties autonomy, party ban, and barriers to parties) and suffrage improve comparatively early. The "late movers" in all episodes are clean election variables (other voting irregularities, vote buying, EMB autonomy) and harassment of journalists. We also provide evidence that this order is almost identical across all episodes 
from 1900 to 2018, regardless of whether they ended in democratic transition or continued autocratic rule. The relatively early development of higher EMB capacity stands out as a distinct component or "genetic marker" of liberalization episodes that eventually succeed. This finding has important policy implications for democracy promotion: donors, civil society organizations, and pro-democracy reform movements may benefit most by prioritizing reforms that enhance the professional capacity of EMBs. While our approach remains descriptive, future research could help unravel whether this relationship is truly causal.

To our knowledge this paper provides the first thorough empirical detailing of how sequences of liberalization unfold. As such, our analyses are but a first building block, and our results open up various avenues for further research. On the one hand, investigating the sequences in more detail and analysing whole chains of variable development would offer further insights on whether there are sequences between groups of variables rather than just pairs. Further analyzing the causal effect that EMB capacity has on the outcome of a democratization episode is another important next step. This would constitute an advancement toward developing an evidence-based theory of endogenous democratization. Finally, the methods we employ here could also be used to detail deliberalization or so-called autocratization episodes, which is especially relevant in the current "third wave of autocratization" (Lührmann and Lindberg, 2019).

\section{References}

Boix, Carles and Susan C. Stokes (2003). "Endogenous Democratization". In: World Politics 55.4, 517-549. DOI: 10.1353/wp.2003.0019.

Bratton, Michael and Nicholas Van de Walle (1997). Democratic experiments in Africa: Regime transitions in comparative perspective. Cambridge university press.

Coppedge, Michael, John Gerring, Carl Henrik Knutsen, Staffan I Lindberg, Jan Teorell, David Altman, Michael Bernhard, M Steven Fish, Adam Glynn, Allen Hicken, Anna Lührmann, Kyle L. Marquardt, Pamela McMann Kelly Paxton, Daniel Pemstein, Brigitte Seim, Rachel Sigman, Svend-Erik Skaaning, Jeffrey Staton, Agnes Cornell, Lisa Gastaldi, Haakon Gjerløw, 
Valeriya Mechkova, Johannes von Römer, Aksel Sundström, Eitan Tzelgov, Luca Uberti, Yi-ting Wang, Tore Wig, and Daniel Ziblatt (2019a). V-Dem Codebook V9.

Coppedge, Michael, John Gerring, Carl Henrik Knutsen, Staffan I. Lindberg, Jan Teorell, David Altman, Michael Bernhard, M. Steven Fish, Adam Glynn, Allen Hicken, Anna Lührmann, Kyle L. Marquardt, Kelly McMann, Pamela Paxton, Daniel Pemstein, Brigitte Seim, Rachel Sigman, Svend-Erik Skaaning, Jeffrey Staton, Steven Wilson, Agnes Cornell, Lisa Gastaldi, Haakon Gjerløw, Nina Ilchenko, Joshua Krusell, Valeriya Mechkova, Juraj Medzihorsky, Josefine Pernes, Johannes von Römer, Natalia Stepanova, Aksel Sundström, Eitan Tzelgov, Yi-ting Wang, Tore Wig, and Daniel Ziblatt (2019b). V-Dem Dataset v9.

Dahl, Robert A. (1971). Polyarchy: Participation and opposition. New Haven: Yale University Press.

- (1989). Democracy and its Critics. Yale University Press.

- (1998). On democracy. Yale University Press.

Donno, Daniela and Anne-Kathrin Kreft (2019). “Authoritarian Institutions and Women's Rights". In: Comparative Political Studies 52.5, pp. 720-753. DOI: 10.1177/0010414018797954. Edgell, Amanda B. (2019). "The Strategic Origins of Electoral Gender Quotas in Authoritarian Regimes". PhD thesis. University of Florida.

Huntington, Samuel P (1968). Political order in changing societies. Yale University Press.

Lindberg, Staffan I., Patrick Lindenfors, Anna Lührmann, Laura Maxwell, Juraj Medzihorsky, Richard Morgan, and Matthew C. Wilson (2018). "Successful and Failed Episodes of Democratization: Conceptualization, Identification, and Description". In: V-Dem Working Papers 79.

Lindenfors, Patrik, Joshua Krusell, and Staffan I Lindberg (2019). "Sequential Requisites Analysis: A New Method for Analyzing Sequential Relationships in Ordinal Data". In: Social science quarterly 100.3, pp. 838-856.

Lindenfors, Patrik, Fredrik Jansson, Yi-ting Wang, and Staffan I Lindberg (2018). "Investigating sequences in ordinal data: A new approach with adapted evolutionary models". In: Political Science Research and Methods 6.3, pp. 449-466. 
Linz, Juan J and Alfred Stepan (1996). Problems of democratic transition and consolidation: Southern Europe, South America, and post-communist Europe. Johns Hopkins University Press.

Lipset, Seymour Martin (1959). "Some social requisites of democracy: Economic development and political legitimacy". In: American Political Science Review 53.1, pp. 69-105.

Lührmann, Anna and Staffan I Lindberg (2019). "A third wave of autocratization is here: what is new about it?" In: Democratization, pp. 1095-1113.

Mechkova, Valeriya, Anna Lührmann, and Staffan I Lindberg (2019). "The Accountability Sequence: From De-jure to De-facto Constraints on Governments". In: Studies in Comparative International Development 54.1, pp. 40-70.

O'Donnell, Guillermo and Philippe C Schmitter (1986). Transitions from authoritarian rule: Tentative conclusions about uncertain democracies. Johns Hopkins University Press.

Przeworski, Adam, Michael Alvarez, José Antonio Cheibub, and Fernando Limongi (2000). Democracy and development: political institutions and well-being in the world, 1950-1990. Vol. 3. Cambridge University Press, Cambridge, UK.

Sillén-Tullberg, Birgitta (1993). "The effect of biased inclusion of taxa on the correlation between discrete characters in phylogenetic trees". In: Evolution 6, pp. 1182-1191.

Teorell, Jan, Michael Coppedge, Staffan I. Lindberg, and Svend-Erik Skaaning (2019). "Measuring polyarchy across the globe, 1900-2017". In: Studies in Comparative International Development 54.1, pp. 71-95.

Wang, Yi-Ting, Patrik Lindenfors, Aksel Sundström, Fredrik Jansson, Pamela Paxton, and Staffan I Lindberg (2017). "Women's rights in democratic transitions: A global sequence analysis, 1900-2012". In: European Journal of Political Research 56.4, pp. 735-756. 


\section{Online appendix}

Table A1. Failed and Successful Democratization Episodes, 1900-2018

\begin{tabular}{lccl}
\hline Country & Start & End & Outcome \\
\hline Afghanistan & 2001 & 2008 & Stabilized electoral autocracy \\
Albania & 1916 & 1922 & Failed liberalization \\
Albania & 1946 & 1947 & Failed liberalization \\
Albania & 1991 & 1993 & Failed liberalization \\
Albania & 2001 & 2005 & Success \\
Algeria & 1962 & 1963 & Failed liberalization \\
Algeria & 1995 & 2002 & Stabilized electoral autocracy \\
Angola & 2008 & 2018 & Censored \\
Argentina & 1912 & 1928 & Success \\
Argentina & 1932 & 1933 & Failed liberalization \\
Argentina & 1946 & 1948 & Failed liberalization \\
Argentina & 1957 & 1961 & Preempted transition \\
Argentina & 1963 & 1965 & Success \\
Argentina & 1972 & 1974 & Preempted transition \\
Argentina & 1983 & 1985 & Success \\
Armenia & 2012 & 2018 & Censored \\
Austria & 1918 & 1923 & Success \\
Azerbaijan & 1991 & 1993 & Stabilized electoral autocracy \\
Bangladesh & 1972 & 1974 & Failed liberalization \\
Bangladesh & 1977 & 1980 & Failed liberalization \\
Bangladesh & 1985 & 1987 & Failed liberalization \\
Bangladesh & 1991 & 1996 & Success \\
Bangladesh & 2009 & 2009 & Preempted transition \\
Barbados & 1944 & 1961 & Success \\
Belarus & 1991 & 1994 & Success \\
Belgium & 1919 & 1921 & Success \\
Belgium & 1944 & 1949 & Success \\
Benin & 1945 & 1961 & Failed liberalization \\
Benin & 1968 & 1969 & Failed liberalization \\
Benin & 1980 & 1995 & Success \\
Bhutan & 1988 & 2013 & Success \\
Bolivia & 1952 & 1961 & Failed liberalization \\
Bolivia & 1982 & 1985 & Success \\
Bosnia and Herzegovina & 1996 & 1998 & Success \\
Botswana & 1960 & 1969 & Success \\
Brazil & 1945 & 1950 & Failed liberalization \\
Brazil & 1967 & 1989 & Success \\
Bulgaria & 1990 & 1991 & Success \\
Burkina Faso & 1949 & 1961 & Failed liberalization \\
Burkina Faso & 1978 & 1979 & Failed liberalization \\
Burkina Faso & 1991 & 1997 & Success \\
Burkina Faso & 2016 & 2018 & Censored \\
\hline & & & \\
\hline
\end{tabular}

continued on next page 
Table A1 - continued from previous page

\begin{tabular}{|c|c|c|c|}
\hline Country & Start Year & End Year & Outcome \\
\hline Burma/Myanmar & 1945 & 1953 & Failed liberalization \\
\hline Burma/Myanmar & 2010 & 2016 & Stabilized electoral autocracy \\
\hline Burundi & 1982 & 1985 & Failed liberalization \\
\hline Burundi & 1992 & 1995 & Failed liberalization \\
\hline Burundi & 1999 & 2006 & Stabilized electoral autocracy \\
\hline Cambodia & 1947 & 1956 & Stabilized electoral autocracy \\
\hline Cambodia & 1981 & 1994 & Stabilized electoral autocracy \\
\hline Cameroon & 1980 & 2015 & Stabilized electoral autocracy \\
\hline Canada & 1920 & 1921 & Success \\
\hline Cape Verde & 1972 & 1975 & Failed liberalization \\
\hline Cape Verde & 1980 & 1991 & Success \\
\hline Central African Republic & 1946 & 1961 & Failed liberalization \\
\hline Central African Republic & 1987 & 2002 & Failed liberalization \\
\hline Central African Republic & 2005 & 2006 & Failed liberalization \\
\hline Central African Republic & 2016 & 2018 & Censored \\
\hline Chad & 1946 & 1957 & Failed liberalization \\
\hline Chad & 1990 & 1997 & Stabilized electoral autocracy \\
\hline Chile & 1932 & 1961 & Success \\
\hline Chile & 1988 & 1993 & Success \\
\hline Colombia & 1903 & 1915 & Stabilized electoral autocracy \\
\hline Colombia & 1958 & 1960 & Failed liberalization \\
\hline Colombia & 1971 & 1975 & Preempted transition \\
\hline Colombia & 1991 & 1991 & Success \\
\hline Comoros & 1979 & 1992 & Failed liberalization \\
\hline Comoros & 1997 & 1997 & Failed liberalization \\
\hline Comoros & 2001 & 2002 & Failed liberalization \\
\hline Comoros & 2004 & 2006 & Success \\
\hline Costa Rica & 1919 & 1924 & Stabilized electoral autocracy \\
\hline Costa Rica & 1950 & 1953 & Success \\
\hline Croatia & 1992 & 1998 & Preempted transition \\
\hline Croatia & 2000 & 2000 & Success \\
\hline Cuba & 1901 & 1903 & Failed liberalization \\
\hline Cuba & 1909 & 1917 & Failed liberalization \\
\hline Cuba & 1936 & 1941 & Stabilized electoral autocracy \\
\hline Cyprus & 1950 & 1968 & Success \\
\hline Cyprus & 1970 & 1970 & Success \\
\hline Czech Republic & 1919 & 1920 & Success \\
\hline Czech Republic & 1990 & 1992 & Success \\
\hline Democratic Republic of the Congo & 1960 & 1961 & Failed liberalization \\
\hline Democratic Republic of the Congo & 2001 & 2009 & Stabilized electoral autocracy \\
\hline Denmark & 1901 & 1903 & Success \\
\hline Denmark & 1945 & 1947 & Success \\
\hline Djibouti & 1992 & 2018 & Censored \\
\hline Dominican Republic & 1924 & 1925 & Failed liberalization \\
\hline Dominican Republic & 1963 & 1963 & Failed liberalization \\
\hline
\end{tabular}


Table A1 - continued from previous page

\begin{tabular}{|c|c|c|c|}
\hline Country & Start Year & End Year & Outcome \\
\hline Dominican Republic & 1966 & 1982 & Success \\
\hline Dominican Republic & 1991 & 1996 & Success \\
\hline Ecuador & 1910 & 1912 & Failed liberalization \\
\hline Ecuador & 1947 & 1962 & Failed liberalization \\
\hline Ecuador & 1967 & 1969 & Failed liberalization \\
\hline Ecuador & 1978 & 1984 & Success \\
\hline Egypt & 1956 & 1976 & Failed liberalization \\
\hline Egypt & 2012 & 2012 & Stabilized electoral autocracy \\
\hline El Salvador & 1982 & 1999 & Success \\
\hline Equatorial Guinea & 1959 & 1969 & Failed liberalization \\
\hline Equatorial Guinea & 1982 & 1996 & Stabilized electoral autocracy \\
\hline Estonia & 1919 & 1920 & Success \\
\hline Estonia & 1993 & 1995 & Success \\
\hline Fiji & 1963 & 1972 & Success \\
\hline Fiji & 1992 & 1994 & Success \\
\hline Fiji & 2002 & 2006 & Success \\
\hline Fiji & 2014 & 2015 & Preempted transition \\
\hline Finland & 1917 & 1919 & Success \\
\hline France & 1945 & 1951 & Success \\
\hline Gabon & 1946 & 1961 & Failed liberalization \\
\hline Gabon & 1990 & 1997 & Stabilized electoral autocracy \\
\hline Georgia & 1993 & 1998 & Failed liberalization \\
\hline Georgia & 2004 & 2004 & Success \\
\hline Germany & 1919 & 1920 & Success \\
\hline Ghana & 1969 & 1971 & Failed liberalization \\
\hline Ghana & 1979 & 1980 & Preempted transition \\
\hline Ghana & 1992 & 2000 & Success \\
\hline Greece & 1924 & 1924 & Failed liberalization \\
\hline Greece & 1945 & 1953 & Failed liberalization \\
\hline Greece & 1974 & 1977 & Success \\
\hline Guatemala & 1945 & 1947 & Failed liberalization \\
\hline Guatemala & 1966 & 1967 & Stabilized electoral autocracy \\
\hline Guatemala & 1984 & 1999 & Success \\
\hline Guinea & 1957 & 1959 & Failed liberalization \\
\hline Guinea & 1985 & 2000 & Failed liberalization \\
\hline Guinea & 2010 & 2016 & Stabilized electoral autocracy \\
\hline Guinea-Bissau & 1992 & 2001 & Failed liberalization \\
\hline Guinea-Bissau & 2004 & 2006 & Preempted transition \\
\hline Guinea-Bissau & 2014 & 2015 & Preempted transition \\
\hline Guyana & 1955 & 1967 & Failed liberalization \\
\hline Guyana & 1986 & 2001 & Success \\
\hline Haiti & 1951 & 1951 & Failed liberalization \\
\hline Haiti & 1987 & 1988 & Failed liberalization \\
\hline Haiti & 1991 & 1991 & Failed liberalization \\
\hline Haiti & 1993 & 1998 & Failed liberalization \\
\hline
\end{tabular}


Table A1 - continued from previous page

\begin{tabular}{lccl}
\hline Country & Start Year & End Year & Outcome \\
\hline Haiti & 2006 & 2007 & Stabilized electoral autocracy \\
Honduras & 1949 & 1950 & Failed liberalization \\
Honduras & 1971 & 1972 & Failed liberalization \\
Honduras & 1980 & 1993 & Success \\
Hungary & 1918 & 1918 & Failed liberalization \\
Hungary & 1920 & 1925 & Failed liberalization \\
Hungary & 1988 & 1990 & Success \\
Iceland & 1904 & 1908 & Success \\
India & 1950 & 1957 & Success \\
India & 1977 & 1977 & Success \\
Indonesia & 1945 & 1956 & Preempted transition \\
Indonesia & 1998 & 2004 & Success \\
Iraq & 2004 & 2008 & Preempted transition \\
Ireland & 1921 & 1922 & Success \\
Israel & 1949 & 1949 & Success \\
Italy & 1901 & 1914 & Failed liberalization \\
Italy & 1944 & 1948 & Success \\
Ivory Coast & 1990 & 1993 & Failed liberalization \\
Ivory Coast & 1995 & 1997 & Failed liberalization \\
Ivory Coast & 2001 & 2004 & Failed liberalization \\
Ivory Coast & 2015 & 2016 & Success \\
Jamaica & 1938 & 1959 & Success \\
Jamaica & 1984 & 1989 & Success \\
Japan & 1945 & 1952 & Success \\
Kenya & 1954 & 1965 & Failed liberalization \\
Kenya & 1990 & 2003 & Stabilized electoral autocracy \\
Kosovo & 2000 & 2004 & Success \\
Kosovo & 2014 & Success \\
Kyrgyzstan & 2013 & 2011 & Failed liberalization \\
Kyrgyzstan & 2010 & 2015 & Success \\
Laos & 2014 & 1948 & Failed liberalization \\
Laos & 1944 & 1958 & Stabilized electoral autocracy \\
Latvia & 1951 & 1925 & Success \\
Lebanon & 1922 & 1953 & Failed liberalization \\
Lebanon & 1923 & 2016 & Preempted transition \\
Lesotho & 2000 & 1967 & Failed liberalization \\
Lesotho & 1952 & 1994 & Failed liberalization \\
Lesotho & 1987 & 2007 & Success \\
Liberia & 2002 & 1986 & Failed liberalization \\
Liberia & 1985 & 1999 & Failed liberalization \\
Liberia & 1991 & 2011 & Success \\
Libya & 2005 & 2013 & Preempted transition \\
Lithuania & 2011 & 1920 & Success \\
Luxembourg & 1920 & Success \\
Luxembourg & 1917 & Success \\
\hline & & \\
\hline
\end{tabular}


Table A1 - continued from previous page

\begin{tabular}{lccl}
\hline Country & Start Year & End Year & Outcome \\
\hline Macedonia & 1994 & 1998 & Success \\
Macedonia & 2001 & 2002 & Success \\
Macedonia & 2015 & 2018 & Censored \\
Madagascar & 1957 & 1971 & Failed liberalization \\
Madagascar & 1975 & 1996 & Success \\
Madagascar & 2013 & 2017 & Stabilized electoral autocracy \\
Malawi & 1960 & 1964 & Failed liberalization \\
Malawi & 1992 & 1999 & Success \\
Malaysia & 1946 & 1962 & Failed liberalization \\
Malaysia & 1972 & 1975 & Stabilized electoral autocracy \\
Malaysia & 1991 & 2011 & Stabilized electoral autocracy \\
Maldives & 1990 & 2009 & Success \\
Mali & 1945 & 1961 & Failed liberalization \\
Mali & 1992 & 1997 & Success \\
Mali & 2014 & 2018 & Success \\
Malta & 1921 & 1922 & Failed liberalization \\
Malta & 1932 & 1933 & Failed liberalization \\
Malta & 1947 & 1950 & Success \\
Malta & 1962 & 1966 & Success \\
Mauritania & 1945 & 1961 & Failed liberalization \\
Mauritania & 1991 & 2002 & Failed liberalization \\
Mauritania & 2007 & 2007 & Failed liberalization \\
Mauritania & 2010 & 2010 & Stabilized electoral autocracy \\
Mauritius & 1948 & 1976 & Success \\
Mexico & 1967 & 1997 & Success \\
Moldova & 1991 & 1994 & Success \\
Moldova & 2009 & 2009 & Success \\
Mongolia & 1989 & 1992 & Success \\
Montenegro & 1999 & 2003 & Preempted transition \\
Namibia & 1985 & 1994 & Success \\
Nepal & 1950 & 1959 & Failed liberalization \\
Nepal & 1982 & 1992 & Failed liberalization \\
Nepal & 2007 & 2009 & Preempted transition \\
Nepal & 2014 & 2017 & Success \\
Netherlands & 1910 & 1918 & Success \\
Netherlands & 1945 & 1948 & Success \\
Nicaragua & 1980 & 1990 & Success \\
Niger & 1957 & 1961 & Failed liberalization \\
Niger & 1988 & 1991 & Failed liberalization \\
Niger & 1993 & 1993 & Success \\
Niger & 2000 & 2004 & Success \\
Niger & 2011 & 2011 & Success \\
Nigeria & 1978 & 1980 & Failed liberalization \\
Nigeria & 1998 & 2000 & Preempted transition \\
Nigeria & 2011 & 2015 & Success \\
\hline & & & \\
\hline
\end{tabular}


Table A1 - continued from previous page

\begin{tabular}{|c|c|c|c|}
\hline Country & Start Year & End Year & Outcome \\
\hline Norway & 1906 & 1906 & Success \\
\hline Norway & 1945 & 1949 & Success \\
\hline Pakistan & 1985 & 1990 & Failed liberalization \\
\hline Pakistan & 2002 & 2010 & Preempted transition \\
\hline Panama & 1904 & 1905 & Failed liberalization \\
\hline Panama & 1947 & 1949 & Failed liberalization \\
\hline Panama & 1953 & 1957 & Failed liberalization \\
\hline Panama & 1973 & 1991 & Success \\
\hline Papua New Guinea & 1946 & 1972 & Success \\
\hline Paraguay & 1987 & 1993 & Success \\
\hline Peru & 1939 & 1946 & Failed liberalization \\
\hline Peru & 1950 & 1960 & Failed liberalization \\
\hline Peru & 1964 & 1964 & Failed liberalization \\
\hline Peru & 1978 & 1985 & Success \\
\hline Peru & 1993 & 1996 & Failed liberalization \\
\hline Peru & 2001 & 2001 & Success \\
\hline Philippines & 1944 & 1968 & Failed liberalization \\
\hline Philippines & 1983 & 1992 & Success \\
\hline Philippines & 2006 & 2010 & Success \\
\hline Poland & 1919 & 1922 & Success \\
\hline Poland & 1984 & 1990 & Success \\
\hline Portugal & 1902 & 1912 & Failed liberalization \\
\hline Portugal & 1970 & 1976 & Success \\
\hline Republic of the Congo & 1945 & 1961 & Failed liberalization \\
\hline Republic of the Congo & 1980 & 1993 & Failed liberalization \\
\hline Republic of the Congo & 2002 & 2003 & Stabilized electoral autocracy \\
\hline Republic of Vietnam & 1946 & 1956 & Failed liberalization \\
\hline Republic of Vietnam & 1966 & 1968 & Stabilized electoral autocracy \\
\hline Romania & 1990 & 1992 & Success \\
\hline Russia & 1987 & 1995 & Preempted transition \\
\hline Rwanda & 1955 & 1962 & Failed liberalization \\
\hline Rwanda & 2003 & 2018 & Censored \\
\hline Sao Tome and Principe & 1987 & 1994 & Success \\
\hline Senegal & 1960 & 1961 & Failed liberalization \\
\hline Senegal & 1968 & 1970 & Failed liberalization \\
\hline Senegal & 1983 & 1988 & Success \\
\hline Serbia & 1980 & 2002 & Success \\
\hline Seychelles & 1963 & 1971 & Failed liberalization \\
\hline Seychelles & 1979 & 1987 & Failed liberalization \\
\hline Seychelles & 1992 & 2006 & Failed liberalization \\
\hline Seychelles & 2008 & 2015 & Success \\
\hline Sierra Leone & 1951 & 1963 & Failed liberalization \\
\hline Sierra Leone & 1994 & 1997 & Failed liberalization \\
\hline Sierra Leone & 2002 & 2007 & Success \\
\hline Singapore & 1946 & 1960 & Failed liberalization \\
\hline
\end{tabular}


Table A1 - continued from previous page

\begin{tabular}{lccl}
\hline Country & Start Year & End Year & Outcome \\
\hline Singapore & 1968 & 2002 & Stabilized electoral autocracy \\
Slovakia & 1994 & 1998 & Success \\
Slovenia & 1990 & 1992 & Success \\
Solomon Islands & 1960 & 1980 & Success \\
Solomon Islands & 2002 & 2004 & Preempted transition \\
Solomon Islands & 2007 & 2010 & Success \\
Somalia & 1941 & 1966 & Stabilized electoral autocracy \\
Somaliland & 1993 & 2010 & Success \\
South Africa & 1989 & 1999 & Success \\
South Korea & 1946 & 1949 & Failed liberalization \\
South Korea & 1964 & 1971 & Failed liberalization \\
South Korea & 1981 & 1988 & Success \\
Spain & 1931 & 1933 & Success \\
Spain & 1968 & 1979 & Success \\
Sri Lanka & 1947 & 1947 & Success \\
Sri Lanka & 2011 & 2015 & Success \\
Sudan & 1940 & 1956 & Failed liberalization \\
Sudan & 1965 & 1966 & Failed liberalization \\
Sudan & 1986 & 1987 & Failed liberalization \\
Sudan & 1997 & 2018 & Censored \\
Suriname & 1946 & 1951 & Success \\
Suriname & 1985 & 1991 & Success \\
Sweden & 1909 & 1924 & Success \\
Syria & 1946 & 1948 & Failed liberalization \\
Syria & 1953 & 1955 & Failed liberalization \\
Syria & 1962 & 1962 & Stabilized electoral autocracy \\
Taiwan & 1970 & 1996 & Success \\
Tanzania & 1958 & 1964 & Failed liberalization \\
Tanzania & 1987 & 1995 & Success \\
Tanzania & 2005 & 2010 & Success \\
Thailand & 1933 & 1938 & Failed liberalization \\
Thailand & 1974 & 1975 & Failed liberalization \\
Thailand & 1979 & 1990 & Failed liberalization \\
Thailand & 1992 & 1995 & Failed liberalization \\
Thailand & 1997 & 1998 & Preempted transition \\
Thailand & 2008 & 2008 & Failed liberalization \\
Thailand & 2011 & 2012 & Preempted transition \\
The Gambia & 1960 & 1962 & Failed liberalization \\
The Gambia & 1966 & 1972 & Success \\
The Gambia & 1996 & 2012 & Failed liberalization \\
The Gambia & 2015 & 2018 & Censored \\
Timor-Leste & 1998 & 2007 & Success \\
Togo & 1944 & 1961 & Failed liberalization \\
Togo & 2008 & Preempted transition \\
Togo & 2015 & Success \\
\hline & & & \\
& 1991 & \\
\hline
\end{tabular}


Table A1 - continued from previous page

\begin{tabular}{lccl}
\hline Country & Start Year & End Year & Outcome \\
\hline Trinidad and Tobago & 1938 & 1966 & Success \\
Tunisia & 1956 & 1967 & Failed liberalization \\
Tunisia & 2005 & 2014 & Success \\
Turkey & 1946 & 1954 & Failed liberalization \\
Turkey & 1962 & 1969 & Success \\
Turkey & 1983 & 1991 & Success \\
Uganda & 1951 & 1963 & Failed liberalization \\
Uganda & 1981 & 1981 & Stabilized electoral autocracy \\
Ukraine & 1992 & 1994 & Success \\
Ukraine & 2003 & 2006 & Success \\
United Kingdom & 1916 & 1922 & Success \\
United States of America & 1920 & 1922 & Success \\
Uruguay & 1911 & 1920 & Success \\
Uruguay & 1922 & 1925 & Success \\
Uruguay & 1936 & 1942 & Success \\
Uruguay & 1980 & 1989 & Success \\
Vanuatu & 1970 & 1983 & Success \\
Venezuela & 1936 & 1948 & Failed liberalization \\
Venezuela & 1958 & 1960 & Stabilized electoral autocracy \\
Vietnam & 1946 & 1947 & Stabilized electoral autocracy \\
Yemen & 1988 & 1993 & Stabilized electoral autocracy \\
Zambia & 1964 & 1965 & Failed liberalization \\
Zambia & 1990 & 1996 & Success \\
Zanzibar & 1980 & 2009 & Stabilized electoral autocracy \\
Zimbabwe & 1979 & 1997 & Stabilized electoral autocracy \\
\hline
\end{tabular}




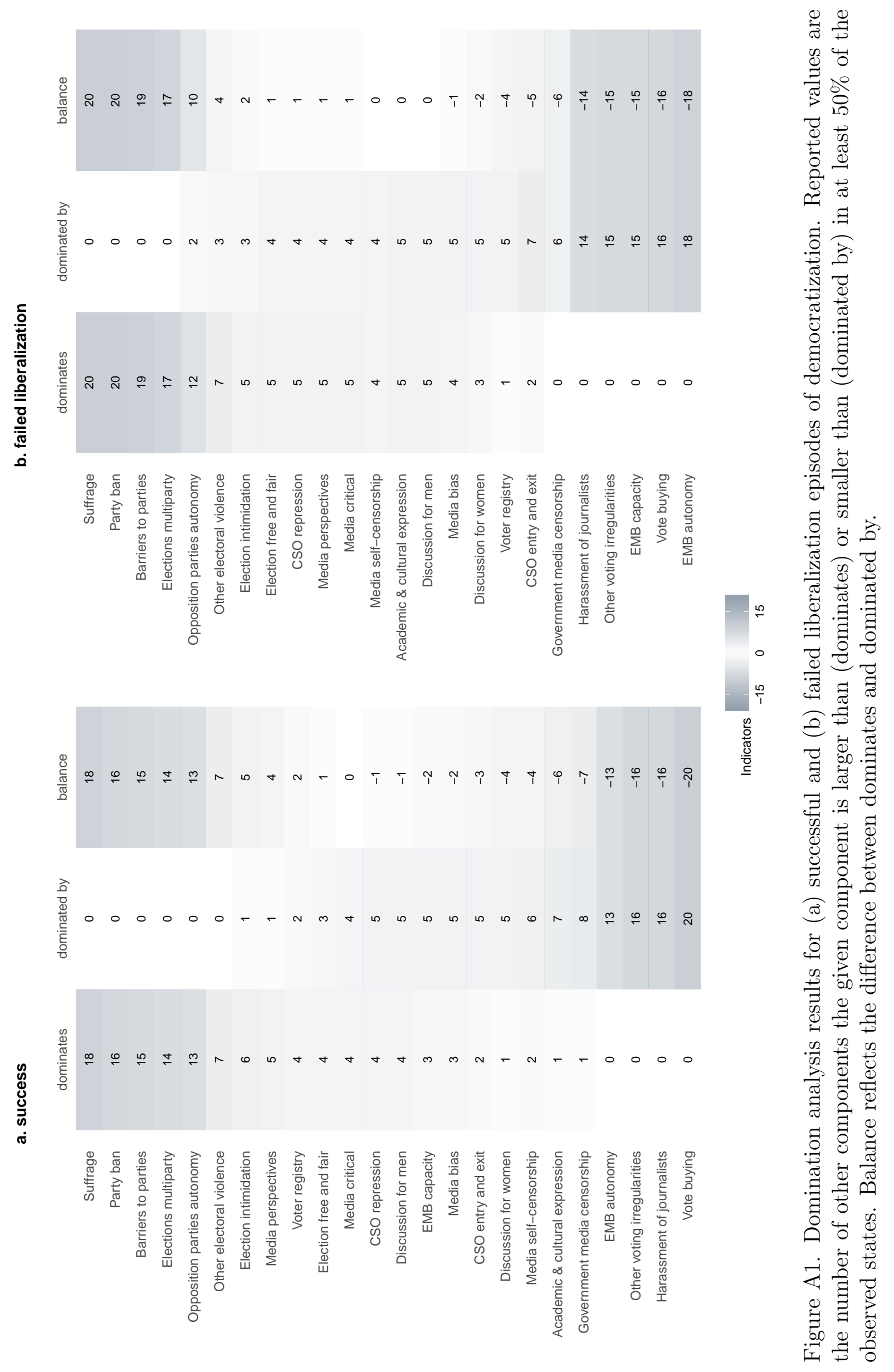




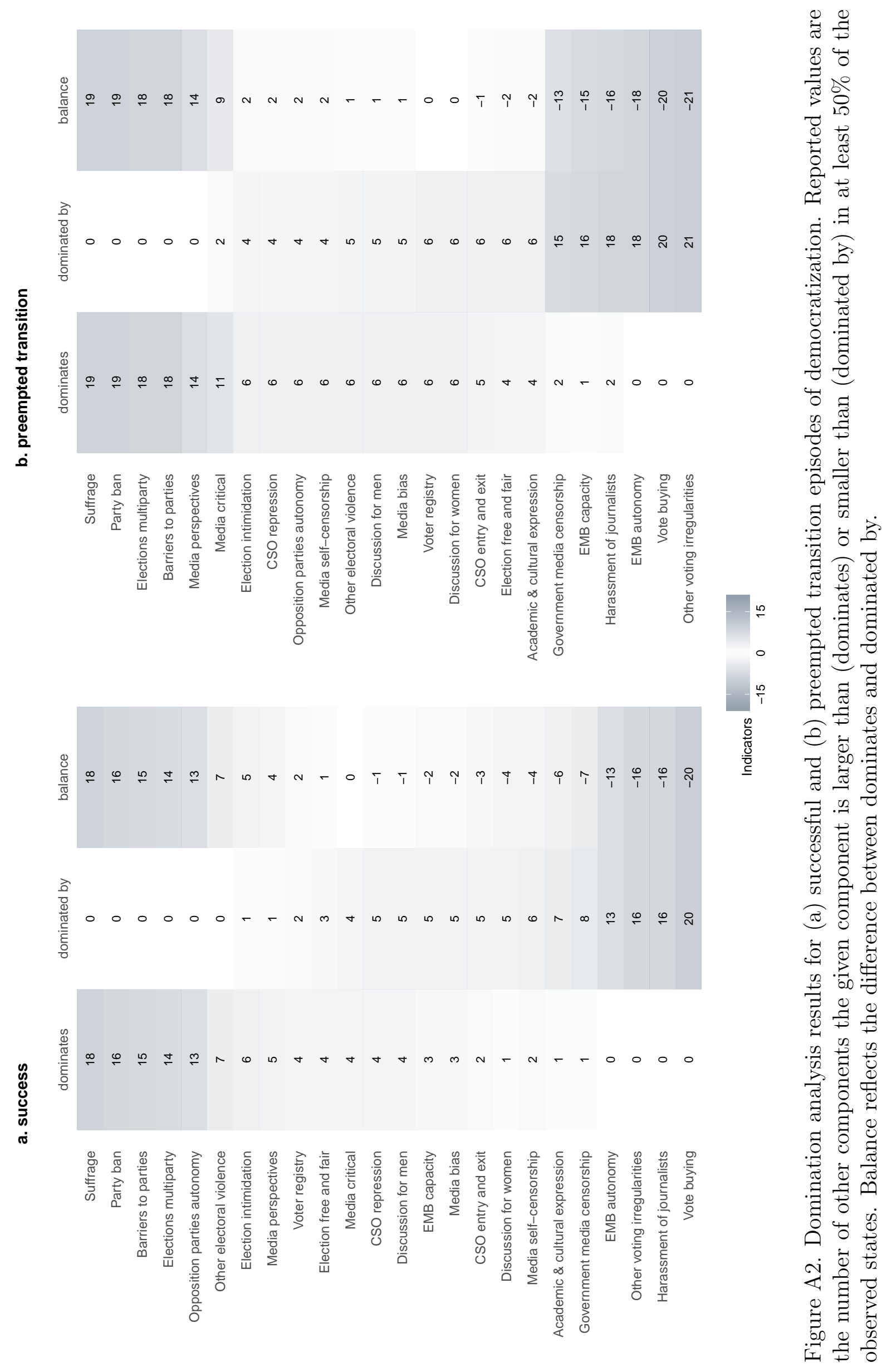




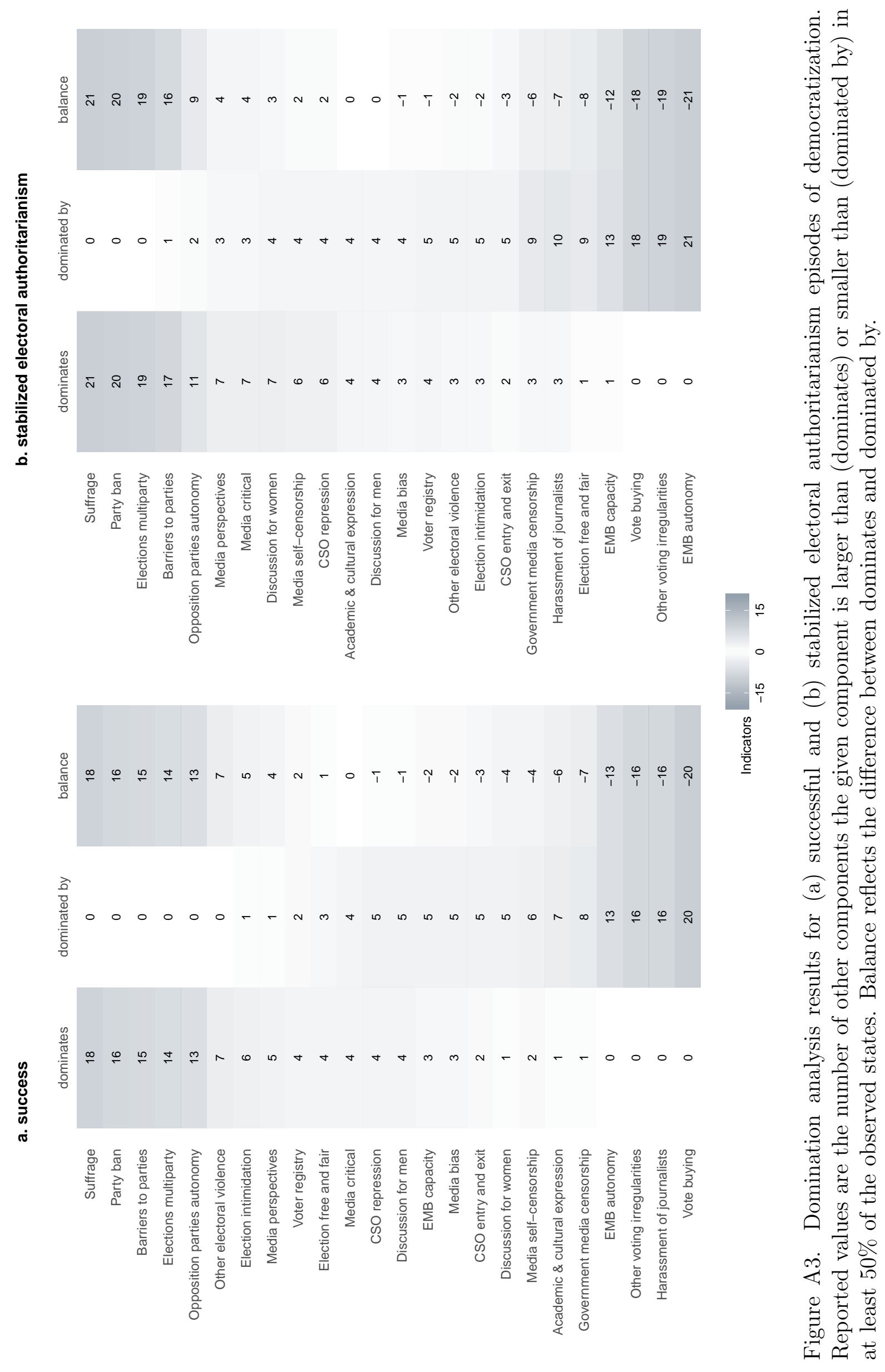




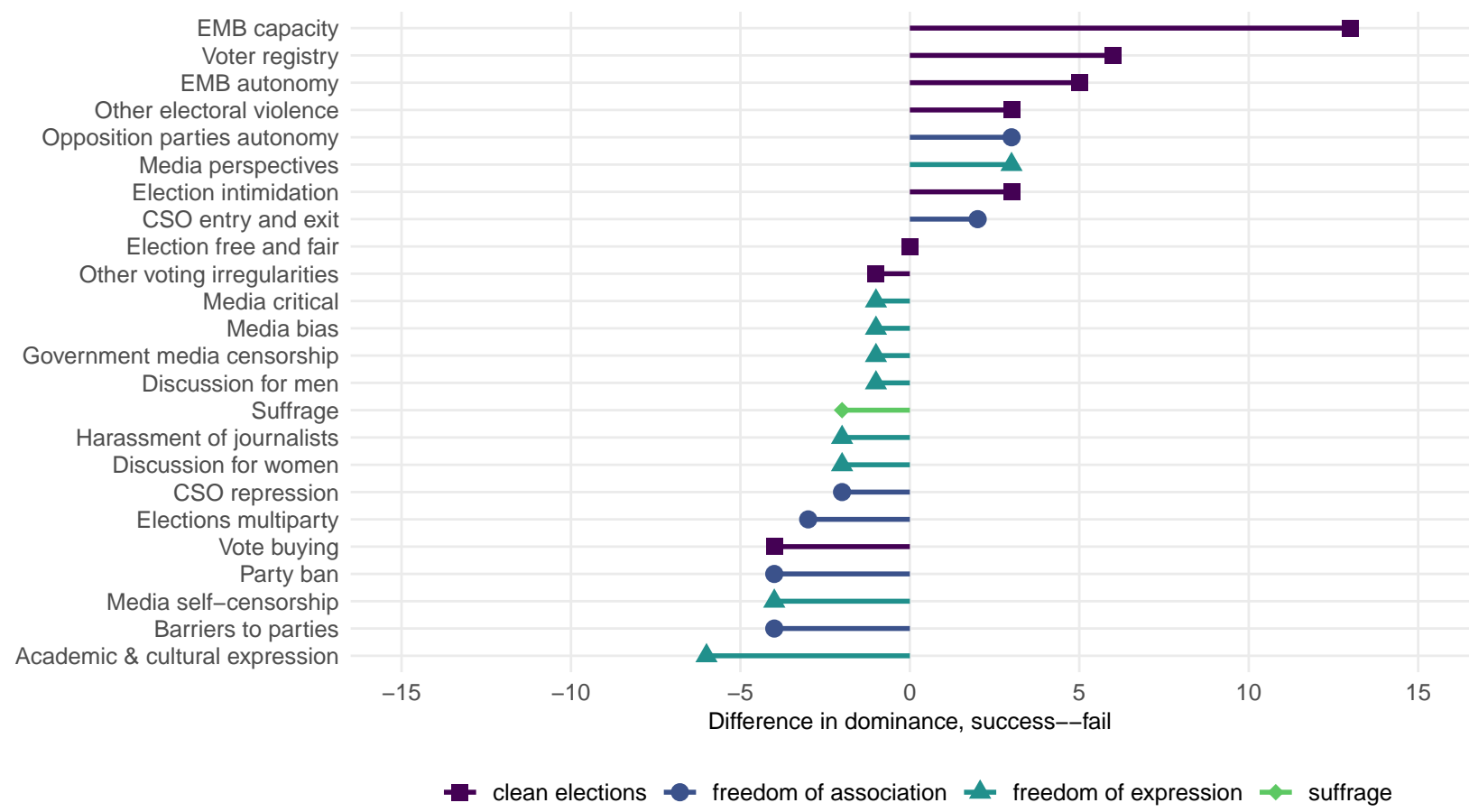

Figure A4. Difference in dominance for successful and failed liberalization episodes. Values are the difference in the balance of indicators the component dominates and is dominated by in successful versus failed liberalization. Higher values suggest that the component develops earlier in successful episodes.

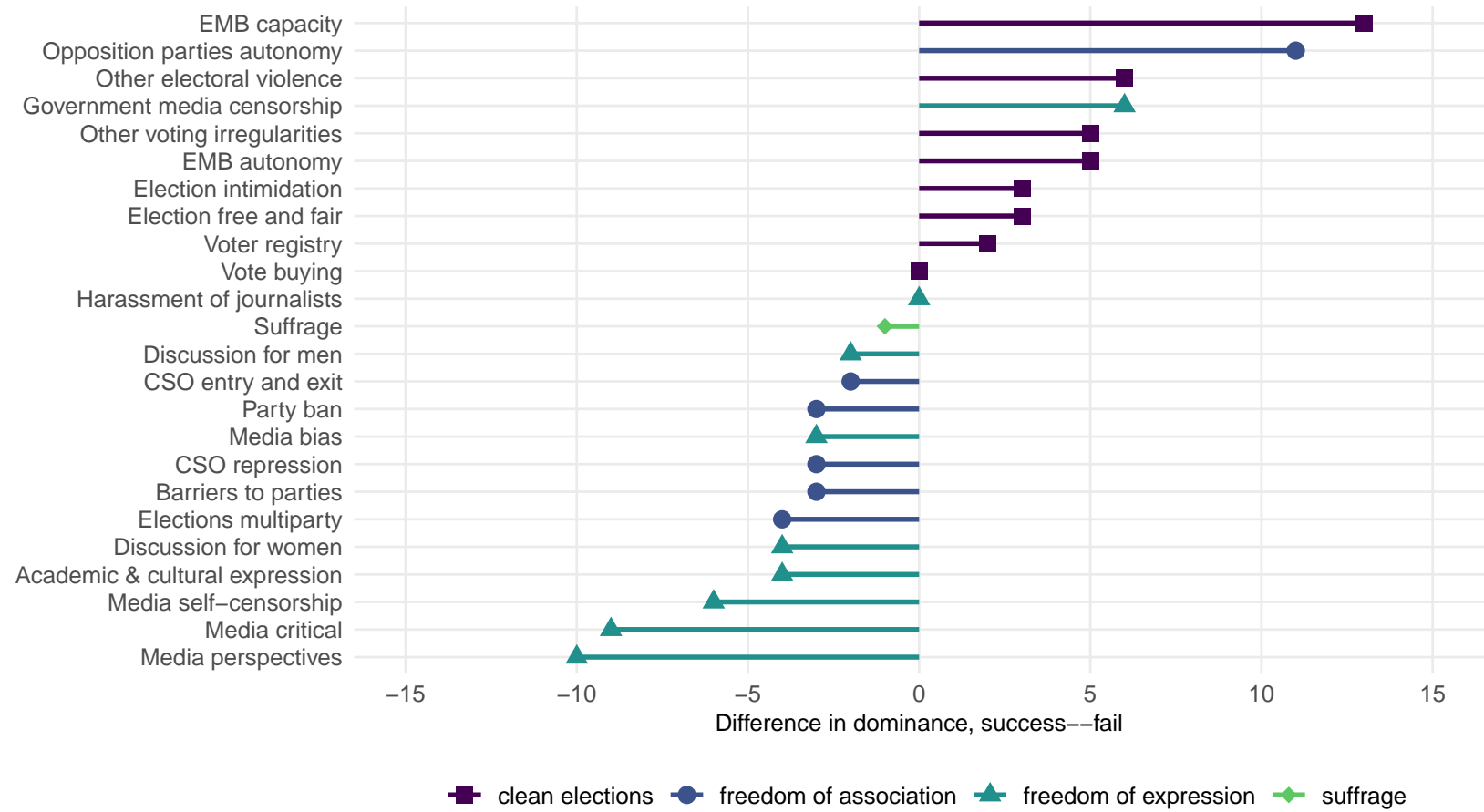

Figure A5. Difference in dominance for successful and preempted transition episodes. Values are the difference in the balance of indicators the component dominates and is dominated by in successful versus preempted transition. Higher values suggest that the component develops earlier in successful episodes. 


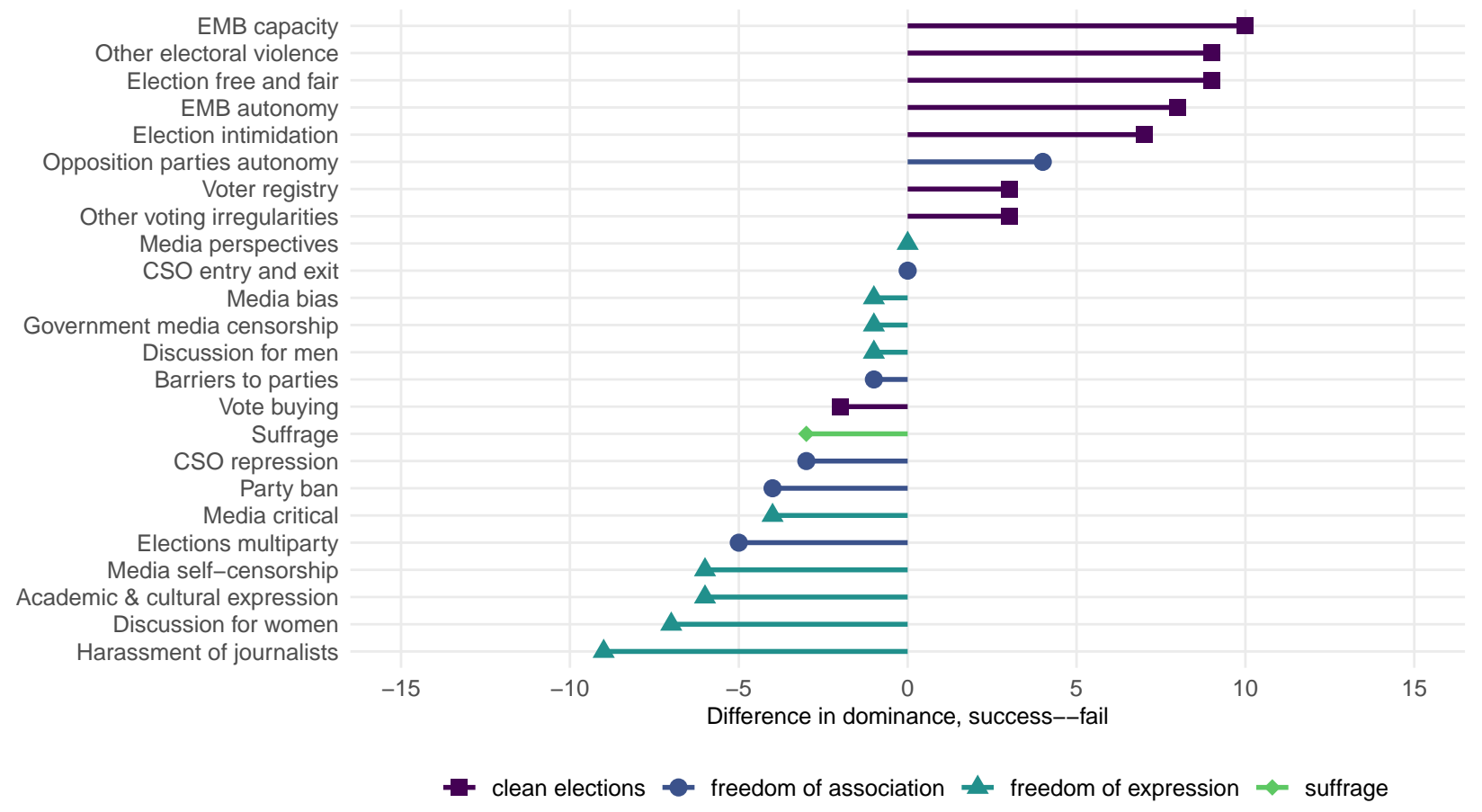

Figure A6. Difference in dominance for successful and stabilized electoral authoritarianism episodes.Values are the difference in the balance of indicators the component dominates and is dominated by in successful versus stabilized electoral authoritarianism. Higher values suggest that the component develops earlier in successful episodes. 


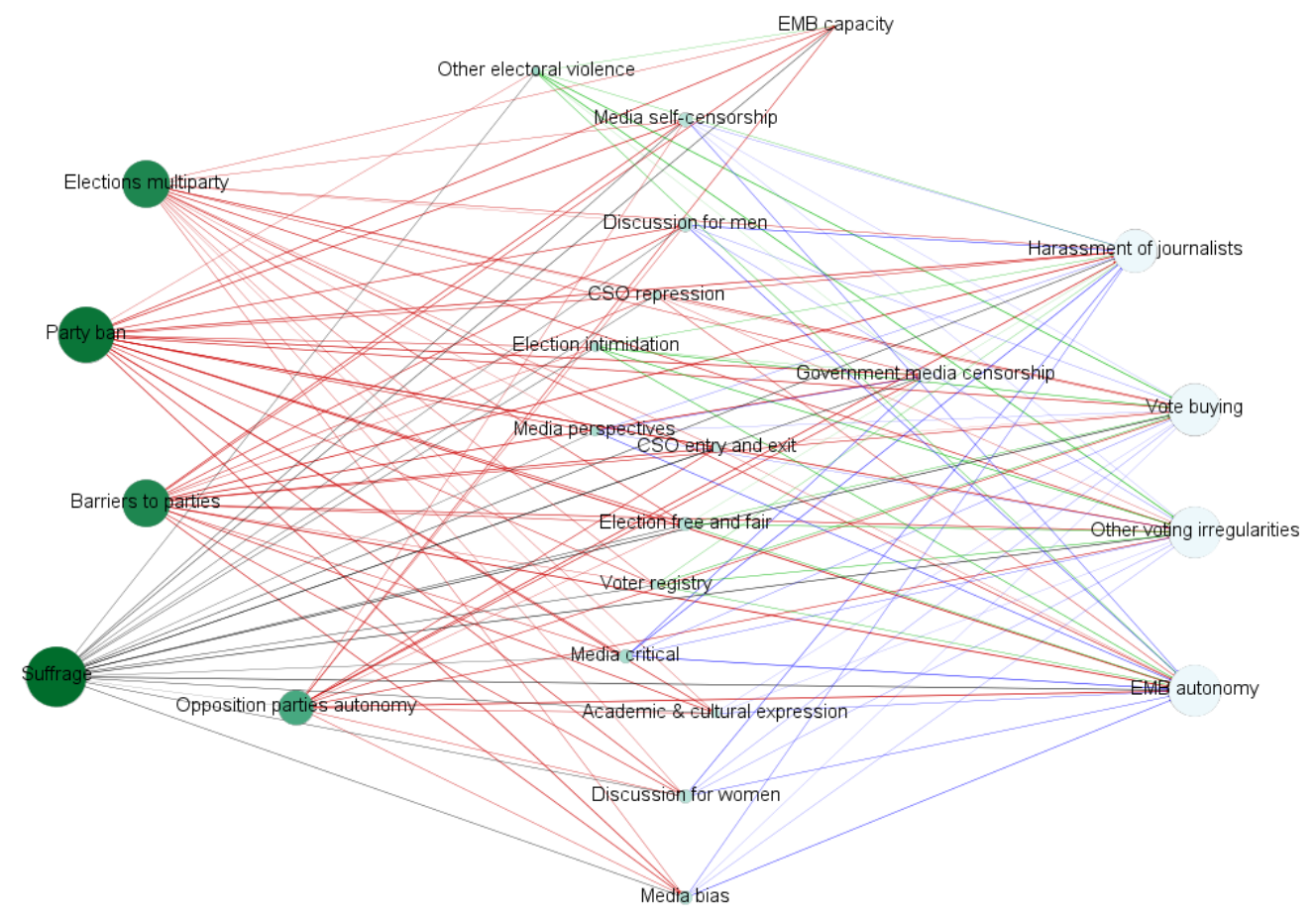

Figure A7. For all episodes: network graph showing domination relationships during democratization episodes. Early variables are situated on the left and late variables on the right (determined by how many variables each variables dominates, minus the number of variables they are dominated by). Nodes and edges are sized based on degree (links to others by weight). Nodes are colored depending on out-degree (green nodes indicate variables that dominate more other variables, whereas white nodes indicate variables that are dominated by more variables). Edge color depends on the subindex of the dominating variable (black: suffrage; red: freedom of association; blue: freedom of expression; green: clean elections). A broad general pattern that this graph conveys is that suffrage and freedom of association are early movers, whereas clean elections and freedom of expression come later. 


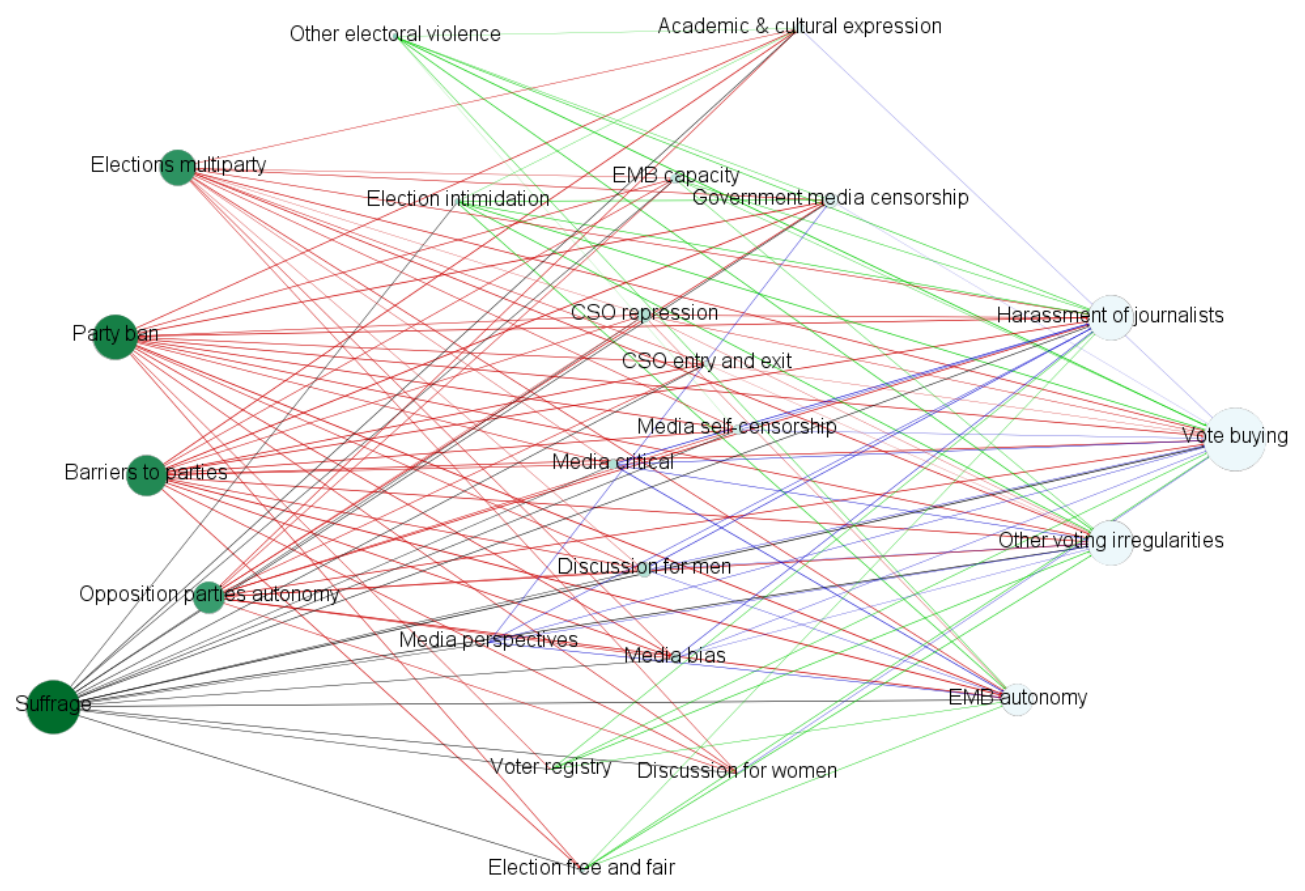

Figure A8. For successful episodes: network graphs showing domination relationships during successful democratization episodes. Early variables are situated on the left and late variables on the right (determined by how many variables each variables dominates, minus the number of variables they are dominated by). Nodes and edges are sized based on degree (links to others by weight). Nodes are colored depending on out-degree (green nodes indicate variables that dominate more other variables, whereas white nodes indicate variables that are dominated by more variables). Edge color depends on the subindex of the dominating variable (black: suffrage; red: freedom of association; blue: freedom of expression; green: clean elections). A result conveyed from comparing these graphs is that the ordering is generally very similar in successful and failed episodes, but that EMB capacity is secured later in failed episodes. 


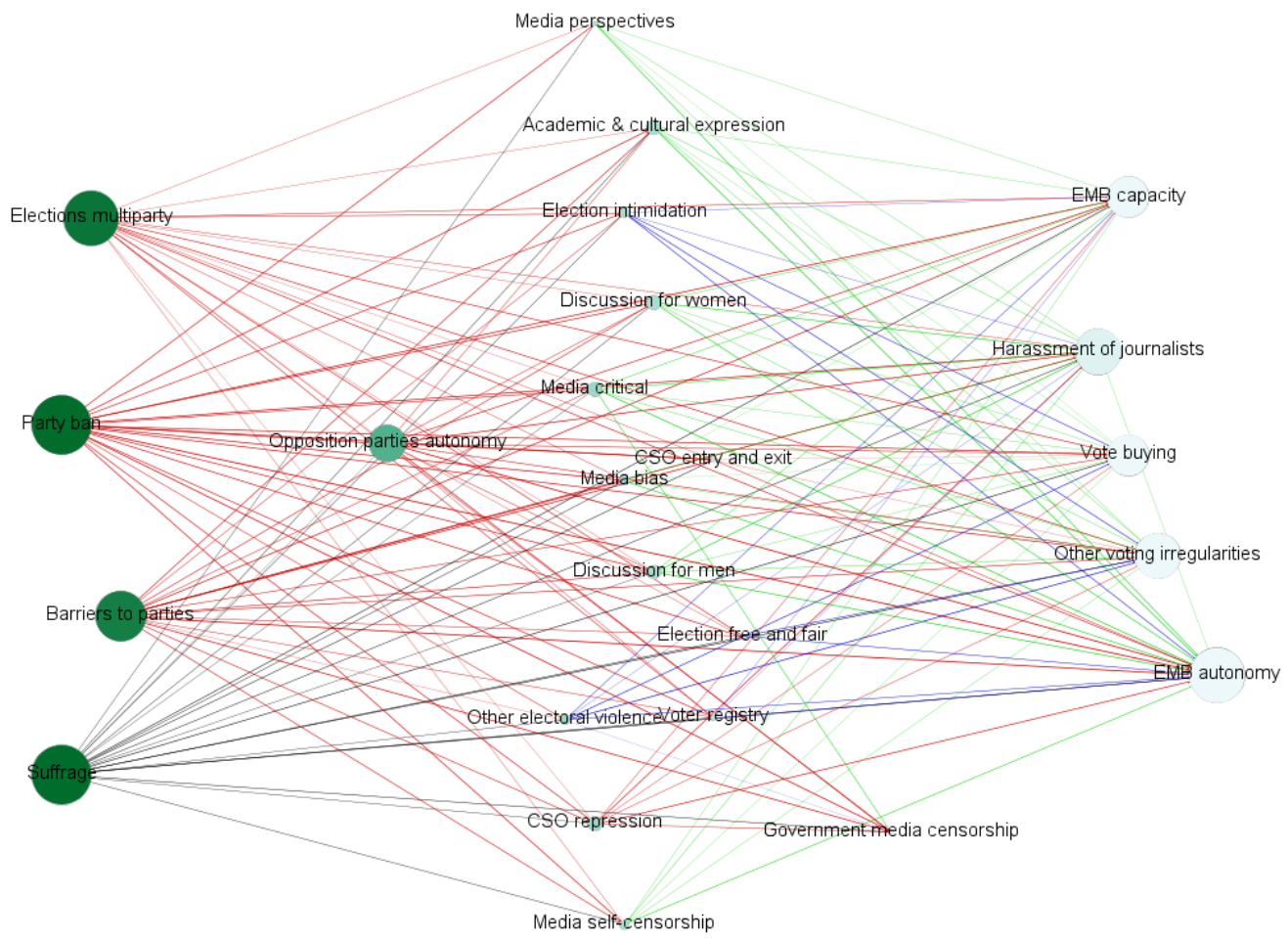

Figure A9. For failed episodes: network graphs showing domination relationships during failed democratization episodes. Early variables are situated on the left and late variables on the right (determined by how many variables each variables dominates, minus the number of variables they are dominated by). Nodes and edges are sized based on degree (links to others by weight). Nodes are colored depending on out-degree (green nodes indicate variables that dominate more other variables, whereas white nodes indicate variables that are dominated by more variables). Edge color depends on the subindex of the dominating variable (black: suffrage; red: freedom of association; blue: freedom of expression; green: clean elections). A result conveyed from comparing these graphs is that the ordering is generally very similar in successful and failed episodes, but that EMB capacity is secured later in failed episodes. 